\title{
Rada Dialogu Społecznego jako platforma wspótpracy rządu oraz strony społecznej
}

Tatiana Wroctawska

Uniwersytet Łódzki, Wydział Prawa i Administracji

Katedra Prawa Pracy

\section{Wstęp}

Temat opracowania dotyka problematyki udziału czynnika społecznego w kształtowaniu polityki społeczno-gospodarczej. Wpisuje się przez to w ramy szerszego kontekstu „budowania kultury zaufania” w stosunkach pomiędzy państwem a obywatelami, stanowiącego warunek sine qua non społeczeństwa obywatelskiego ${ }^{1}$. Akceptacja dialogu społecznego jako jednego $\mathrm{z}$ istotnych instrumentów rządzenia rodzi potrzebę stworzenia odpowiednich warunków prawnych i faktycznych do jego rozwoju, a tym samym określenia procedur komunikowania się między władzą a społeczeństwem na różnych płaszczyznach. Jedną z nich jest konsultowanie i uzgadnianie decyzji prawotwórczych. Podkreśla się, że udział czynnika społecznego w decyzjach prawotwórczych jest „elementem tzw. deliberacyjnego modelu demokracji, który próbuje godzić w ramach ustroju demokratycznego dwie wartości: legitymację i racjonalność procesu decyzyjnego"2. Trafnie się zauważa, że włączanie partnerów społecznych do procesu prawotwórczego wychodzi naprzeciw dyrektywom państwa demokratycznego, takim jak pewność prawa i zaufanie obywateli do państwa ${ }^{3}$. Znaczenie udziału czynnika społecznego z punktu widzenia prawidłowego przebiegu postępowania ustawodawczego akcentuje również Trybunał Konstytucyjny, podkreślając, że występowanie o opinie do uprawnionych podmiotów jest stałym i istotnym elementem procesu legislacyjnego, zwłaszcza wówczas, gdy konsultacje są wymagane ustawą. Dotyczy to zwłaszcza projektów rządowych, które nie mogą być przesyłane do Sejmu przed zakończeniem procedury opiniowania przez partnerów społecznych ${ }^{4}$. Implikuje to jednak podstawowe

1 Zob. S. Patyra, Konsultacje społeczne w procesie przygotowywania rzq̨dowych projektów ustaw - zarys problemu, „Studia luridica Lublinensia” 2014, nr 22, s. 498-499.

2 Por. ibidem.

3 Ibidem.

4 Zob. wyroki Trybunału Konstytucyjnego, podane w opracowaniu S. Patyry, Konsultacje spoteczne..., s. 499-500. 
pytanie o to, w jakim stopniu „demokratycznie legitymizowane organy władzy powinny uwzględniać w procesie decyzyjnym głosy partnerów społecznych, w sensie formalnym uważanych za niekompetentnych, ale będących ważnymi wyrazicielami opinii publicznej"

Ustawa z 2015 r. wprowadza nową, rozszerzoną formułę dialogu społecznego, ukazującą dalej idące uspołecznienie mechanizmów podejmowania decyzji publicznych. W związku z powyższym w tym opracowaniu w pierwszej kolejności omówiono proces zmiany paradygmatu dialogu społecznego, w wyniku którego doszło do wykształcenia się zinstytucjonalizowanej formy dialogu partnerów społecznych ze stroną rządową, a także przedstawiono uwagi dotyczące organizacji działalności i uprawnień Rady Dialogu Społecznego (dalej: Rada). W dalszej części - mając na względzie właściwość działania - omówiono strukturę i pozycję stron Rady, jak również dokonano oceny przyjętej formuły trójstronnego dialogu społecznego.

\section{Rys historyczny oraz charakterystyka zmian w zakresie instytucji dialogu społecznego}

Zgodnie z preambułą Konstytucji Rzeczypospolitej Polskiej z dnia 2 kwietnia z 1997 r. ${ }^{6}$ dialog społeczny stanowi zasadę, na której opierają się „prawa podstawowe dla państwa". Z kolei art. 20 Konstytucji RP stanowi o zasadzie solidarności, dialogu i współpracy partnerów społecznych jako podstawach ustroju gospodarczego Rzeczypospolitej Polskiej ${ }^{\top}$. Podkreślenia wymaga, że pomimo nadania powyższej zasadzie szczególnego znaczenia ustrojowego, Rada Dialogu Społecznego nie posiada umocowania konstytucyjnego ${ }^{8}$.

Istotne jest, że chociaż liczne akty normatywne, włącznie z ustawą zasadniczą, odwołują się do dialogu społecznego, to brakuje jego zdefiniowania ${ }^{9}$. Nie jest on też jednolicie pojmowany ${ }^{10}$. Powodów takiego stanu jest jednak wiele. W zależ-

5 Wskazuje na to S. Patyra, Konsultacje społeczne..., s. 498.

6 Dz.U. z 1997 r., nr 78, poz. 483.

7 Zob. uwagi W. Sanetry w przedmiocie preambuły oraz art. 20 Konstytucji RP: W. Sanetra, Prawnokonstytucyjne uwarunkowania zakładowego dialogu partnerów społecznych, [w:] J. Stelina (red.), Zakładowy dialog społeczny, Warszawa 2014, s. 19-22.

8 Inaczej zostało to uregulowane w niektórych państwach Europy, czego szczególnym przykładem jest Francja.

9 Zob. o tym: K. Walczak, Dialog społeczny, [w:] System zbiorowego prawa pracy, t. V: Zbiorowe prawo pracy, red. K. W. Baran, Warszawa 2014, s. 945-951.

10 Zob. W. Sanetra, Prawnokonstytucyjne uwarunkowania..., s. 23. Por. uwagi autora w przedmiocie rozumienia następujących konstytucyjnych pojęć: „dialog”, „dialog społeczny”, „dialog 
ności od celu, podmiotów i zakresu przedmiotowego możemy wyróżnić dialog dwustronny, trójstronny, wielostronny, zakładowy, ponadzakładowy oraz ogólnokrajowy ${ }^{11}$. Z kolei, mając na względzie określone formy dialogu, można też mówić o konsultacjach, opiniach, stanowiskach, porozumieniach, uzgodnieniach bądź zgodach. Tym samym znaczeń oraz definicji dialogu społecznego, nadawanych zresztą przez poszczególne dziedziny nauki, jest wiele. Podawane w literaturze wyjaśnienie leksykalne wydaje się jednak trafnie oddawać istotę tej instytucji. Rozmowy, negocjacje oraz osiągnięcie porozumienia (kompromisu) w ważnych sprawach społecznych stanowią bowiem główny cel dialogu - i to bez względu na jego przedmiot, podmioty czy formę. W ujęciu ogólnym określa się go jako środek do rozwiązywania problemów ekonomicznych i społecznych ${ }^{12}$.

Dość rozpowszechnione jest także utrzymywanie dialogu społecznego w konwencji określonego typu relacji pomiędzy różnymi podmiotami $\mathrm{z}$ udziałem państwa jako partnera ${ }^{13}$. Spotkać się też możemy z określaniem go mianem demokracji konsensualnej ${ }^{14}$. Pomimo wielu zróżnicowanych ujęć dość tradycyjnie wyodrębniane są jego cechy szczególne, a więc takie, bez których dialog społeczny miałby charakter jedynie pozorny. W pewnym skrócie należy do nich zaliczyć niezależność i reprezentatywność organizacji partnerów społecznych, równowagę sił stron dialogu oraz prowadzenie negocjacji w tzw. dobrej wierze ${ }^{15}$. Stąd pełna efektywność dialogu społecznego możliwa jest jedynie w warunkach demokratycznych ${ }^{16}$.

Mając powyższe na względzie, nie dziwi, że warunki umożliwiające wykształcenie się zinstytucjonalizowanej formy dialogu społecznego powstały dopiero wraz z pojawieniem się niezależnych sił społecznych w postaci wolnych związków zawodowych i organizacji pracodawców. Symboliczną datą jest w tym przypadku rok 1989, rozpoczynający nowy ustrój w Polsce. Do tego czasu w ówczesnych uwarunkowaniach „omnipotencji gospodarczej państwa” brakowało strony pracodawczej jako partnera do rozmów, z kolei negocjacje z klasą robotniczą przybierały

partnerów społecznych” i „partnerzy społeczni”; dialog stanowi oparcie dla społecznej gospodarki rynkowej: ibidem, s. 22-25.

11 Wskazuje się w związku z powyższym na potrzebę zakreślania granic pojęcia dialogu społecznego: L. Florek, Prawnomiędzynarodowe uwarunkowania zakładowego dialogu społecznego, [w:] J. Stelina (red.), Zakładowy dialog..., s. 47.

12 Por. uwagi L. Florka w przedmiocie rozumienia dialogu w prawie międzynarodowym: ibidem, s. $36,46$.

13 Zob. uwagi na temat „dialogu społecznego” oraz „dialogu partnerów społecznych” W. Sanetra, Prawnokonstytucyjne uwarunkowania..., s. 23.

14 Por. K. Walczak, Dialog społeczny..., s. 945-951.

15 Szerzej o warunkach dialogu społecznego, w tym od strony podmiotowej: M. Pliszkiewicz, Warunki trójstronnego dialogu społecznego, [w:] Z. Hajn, D. Skupień (red.), Przyszłość prawa pracy. Liber Amicorum. W pięćdziesięciolecie pracy naukowej Profesora Michała Seweryńskiego, Warszawa 2016, s. 473-475.

16 L. Florek, Prawnomiędzynarodowe uwarunkowania..., s. 46. 
bardziej formy konfliktów niż dialogu ${ }^{17}$. Niemniej jednak, mimo że podstawę do rozwoju i powstania instytucjonalnych podstaw dialogu społecznego wyznaczyła wspomniana data, to proces miał charakter wieloetapowy i był zdecydowanie wydłużony w czasie. Nie bez znaczenia dla wykształcenia się ram prawnych instytucji dialogu społecznego był fakt ponad dwudziestoletniego okresu funkcjonowania Komisji Trójstronnej ds. Społeczno-Gospodarczych, datowany uchwałą Rady Ministrów z 15 lutego 1994 r. $(7 / 94)^{18}$. Wsparta konstytucyjnym umocowaniem dialogu w 1997 r. instytucja ta przybrała jednak jednolity charakter dopiero na mocy ustawy o Komisji Trójstronnej ds. Społeczno-Gospodarczych i wojewódzkich komisjach dialogu społecznego $\mathrm{z}$ dnia 6 lipca $2001 \mathrm{r}^{19}$

Zmiana koncepcji dialogu, a tym samym paradygmatu dialogu trójstronnego, nastąpiła w 2013 r. Za główny impuls do tego posłużyło zawieszenie prac przez trzy reprezentatywne organizacje pracowników w ramach Komisji Trójstronnej, a także we wszystkich innych platformach współpracy trójstronnej. W ich wyniku doszło do powstania długotrwałego impasu w zakresie dialogu społecznego. Stanowisko zajmowane przez pracowniczą stronę związkową uzasadniane było lekceważeniem postulatów partnerów społecznych przez ówczesny rząd. Okoliczność ta miała też istotny wpływ na ostateczny kształt nowej ustawy. W ramach konsultacji nad ustanowieniem nowych ram dla dialogu społecznego podkreślano potrzebę zmiany zakresu i trybu działania instytucji dialogu oraz nadania mu nowej formuły prawnej, dostosowanej do współczesnych wymagań i oczekiwań partnerów społecznych ${ }^{20}$. W konsekwencji projekt ustawy skumulował zaproponowane przez partnerów społecznych rozwiązania, stanowiące wspólnie wypracowany kompromis. W wyniku tych działań 24 lipca 2015 r. przyjęto nową ustawę o Radzie Dialogu Społecznego i innych instytucjach dialogu społecznego ${ }^{21}$ (dalej: u.r.d.s.), w ramach której, mając na względzie postulaty strony społecznej, dokonano przewartościowania koncepcji dialogu społecznego, w tym zredefiniowano cele oraz instrumenty służące do jego prowadzenia.

17 Por. J. Wratny, Rada Dialogu Społecznego. Czy jeszcze instytucja zbiorowego prawa pracy?, „Praca i Zabezpieczenie Społeczne” 2016, nr 10, s. 2-3. Zob. też uwagi o przemianach po 1989 r., stwarzających podstawę do wykształcenia się instytucji dialogu społecznego: K. Walczak, Dialog społeczny..., s. 964-970.

18 Por. J. Wratny, Rada Dialogu Społecznego..., s. 3.

19 Dz.U. z 2001 r., nr 100, poz. 1080 ze zm.

20 O tym J. Wratny, Rada Dialogu Społecznego..., s. 4. Zob. też szczegółowe uwagi na temat przesłanek i powodów zmian w odniesieniu do instytucji dialogu społecznego: M. Pliszkiewicz, Warunki trójstronnego dialogu..., s. 469-471.

21 Dz.U. z 2015 r., poz. 1240. 


\section{Organizacja działalności i kompetencje Rady Dialogu Społecznego}

Zasad funkcjonowania Rady Dialogu Społecznego nie sposób ocenić bez porównania sposobu organizacji działalności tej instytucji z regulacją poprzednio obowiązującej ustawy z 2001 r. Na jej podstawie dialog w ramach Komisji Trójstronnej ds. Społeczno-Gospodarczych (dalej: Komisja) był prowadzony w celu godzenia interesów pracowników, pracodawców oraz dobra społecznego, z kolei celem działalności Komisji było dążenie do zachowania pokoju społecznego. Ustawa z 2015 r. uczyniła z Rady forum trójstronnej współpracy strony pracowników, strony pracodawców oraz strony rządowej, w ramach którego dialog jest prowadzony w celu zapewnienia warunków rozwoju społeczno-gospodarczego oraz zwiększenia konkurencyjności polskiej gospodarki i spójności społecznej. Na podkreślenie zasługuje wyłączenie zasady pokoju społecznego jako głównego obszaru właściwości działania instytucji dialogu społecznego oraz rezygnacja $\mathrm{z}$ zastosowania osłony w postaci dobra publicznego, za którą kryła się strona rządowa. W wyniku noweli art. 1 u.r.d.s. na mocy ustawy z dnia 5 lipca 2018 r. o zmianie ustawy o związkach zawodowych oraz niektórych innych ustaw ${ }^{22}$ od 1 stycznia 2019 r. zmieniono zakres podmiotowy strony pracowników. W związku z rozszerzeniem zasady wolności zrzeszania się strona pracowników w Radzie reprezentuje osoby wykonujące pracę zarobkową w rozumieniu art. $1^{1}$ pkt 1 ustawy z dnia 23 maja 1991 r. o związkach zawodowych ${ }^{23}$. Pod tym pojęciem należy rozumieć pracowników lub osoby świadczące pracę za wynagrodzeniem na innej podstawie niż stosunek pracy, jeżeli nie zatrudniają do tego rodzaju pracy innych osób, niezależnie od podstawy zatrudnienia, oraz mają takie prawa i interesy związane $z$ wykonywaniem pracy, które mogą być reprezentowane i bronione przez związek zawodowy.

Inne są również cele działalności Rady. Zgodnie z art. 1 u.r.d.s. zalicza się do nich: realizację zasady partycypacji i solidarności społecznej w zakresie stosunków zatrudnienia, poprawę jakości formułowania i wdrażania polityk oraz strategii społeczno-gospodarczych, a także budowanie wokół nich społecznego porozumienia $\mathrm{w}$ drodze prowadzenia przejrzystego, merytorycznego i regularnego dialogu organizacji pracowników, pracodawców i strony rządowej. Ponadto Rada wspiera prowadzenie dialogu na wszystkich szczeblach jednostek samorządu terytorialnego. Mając powyższe rozwiązania na względzie, w literaturze podkreśla się, że w nowej ustawie cele stricte pracownicze zostały zdecydowanie przysłonięte przez nowe cele ekonomiczne oraz ogólnospołeczne ${ }^{24}$.

22 Dz.U.z 2018 r., poz. 1608.

23 Dz.U. z 2015 r., poz. 1881 oraz Dz.U. z 2018 r., poz. 1608.

24 Tak J. Wratny, Rada Dialogu Społecznego..., s. 5. 
Rozszerzonej formule dialogu społecznego towarzyszą szersze kompetencje Rady, podzielone - według kryterium podmiotowego - na realizowane $\mathrm{w}$ formie uchwał strony społecznej (uchwały dwustronne) oraz podejmowane przez wszystkie strony Rady: stronę pracowników, stronę pracodawców i stronę rządową (uchwały trójstronne). Mając na względzie zróżnicowany charakter poszczególnych uprawień Rady, w literaturze podejmowane są próby ich pogrupowania. Przykładowo, wyodrębnia się: uprawnienia obligatoryjne, szczegółowo uregulowane przez ustawodawcę oraz obwarowane terminami; uprawnienia zdefiniowane, określone przez ustawodawcę, ale ich realizacja pozostawiona została inicjatywie strony społecznej; uprawnienia ogólne, polegające na potencjalnej możliwości do ich inicjowania ${ }^{25}$. Zaproponowany podział obrazuje też pozycję stron Rady, w tym ukazuje przeważający udział strony społecznej, o czym będzie mowa dalej.

Artykuł 2 ust. 1-3 u.r.d.s. określa kompetencje Rady, stanowiąc, że do właściwości Rady oraz jej stron należy zajmowanie stanowisk i wyrażanie opinii, opiniowanie projektów założeń projektów ustaw oraz projektów aktów prawnych, a od dnia 31 sierpnia $2018 \mathrm{r}^{26}$, poza projektem ustawy budżetowej, również opiniowanie Wieloletniego Planu Finansowego Państwa, projektów strategii, projektów programów oraz projektów innych dokumentów rządowych dotyczących planowanych działań Rady Ministrów, przygotowywanych przez Radę Ministrów i jej członków, a także inicjowanie procesu legislacyjnego na zasadach określonych w ustawie. Z powyższego wynika, iż zasadnicza część uprawnień Rady odnosi się do jej współuczestniczenia w procesie tworzenia prawa. Znajdują one też potwierdzenie w nałożonych na organy władzy obowiązkach konsultowania projektów ustaw. $\mathrm{Na}$ szczególną uwagę zasługuje w tym miejscu opiniowanie projektów rządowych ${ }^{27}$. Na podstawie Regulaminu Sejmu ${ }^{28}$ stanowi się, że uzasadnienie projektu ustawy powinno przedstawiać wyniki przeprowadzanych konsultacji oraz informować o przedstawionych wariantach i opiniach, w szczególności jeżeli obowiązek zasięgania takich opinii wynika z przepisów ustawy. Pojawia się w związku z powyższym pytanie o konsekwencje naruszenia wymienionych wyżej obowiązków. Na podstawie Regulaminu Sejmu w razie niedochowania obowiązku przeprowadzenia wymaganych konsultacji społecznych Marszałek Sejmu może zwrócić projekt ustawy wnioskodawcy ${ }^{29}$. Warte przywołania jest w tym zakresie stanowisko

25 J. Męcina, Komentarz do ustawy o Radzie Dialogu Społecznego i innych instytucjach dialogu społecznego, [w:] Zbiorowe prawo pracy. Komentarz, Warszawa 2016, art. 2, teza 3.

26 Ustawa z dnia 15 czerwca 2018 r. o zmianie ustawy o Radzie Dialogu Społecznego i innych instytucjach dialogu społecznego, Dz.U. z 2018 r., poz. 1464.

27 Zob. szerzej o tym: S. Patyra, Konsultacje społeczne..., s. 505-508. Zob. również obwieszczenie Prezesa Rady Ministrów z dnia 11 października 2016 r. w sprawie ogłoszenia jednolitego tekstu uchwały Rady Ministrów - Regulamin pracy Rady Ministrów, M.P. z 2016 r., poz. 1006.

28 Uchwała Sejmu RP z dnia 30 lipca 1992 r. - Regulamin Sejmu Rzeczypospolitej Polskiej (ostatnia zmiana z dnia 14 czerwca 2018 r.), tekst dostępny na: http://www.sejm.gov.pl/prawo/regulamin/kon7.htm (dostęp: 20.09.2018).

29 Art. 34 ust. 3 i ust. 7 Regulaminu Sejmu. 
uznające, że pominięcie obligatoryjnych konsultacji społecznych ze względu na naruszenie procedury ustawodawczej może stanowić podstawę do postawienia zarzutu niekonstytucyjności ustawy ${ }^{30}$. Tymczasem, gdy chodzi o stanowisko Trybunału Konstytucyjnego, podkreślenia wymaga, że wyrażane były zarówno poglądy o poważnym naruszeniu trybu postepowania, jak i braku możliwości przypisania automatycznego naruszenia norm konstytucyjnych ${ }^{31}$.

Przedmiotowa ustawa nie reguluje wyczerpująco wszystkich kompetencji Rady, która w zakresie objętym właściwością wykonuje ponadto zadania wynikające z odrębnych ustaw (art. 2 ust. 4 u.r.d.s.). Można tutaj wskazać na kilka wiodących przykładów. Odnoszą się one do szczególnego uprawnienia Rady, określanego mianem „uzgadniania", które wpisuje się w ramy tzw. obligatoryjnych kompetencji Rady. Uzgodnieniu w drodze uchwały Rady Dialogu Społecznego podlegają kwoty średniorocznych wskaźników wzrostu wynagrodzeń w państwowej sferze budżetowej ${ }^{32}$, a także kwoty minimalnego wynagrodzenia miesięcznego i minimalnej stawki godzinowej ${ }^{33}$. Uzgodnienie przez Radę (w drodze uchwały) wysokości średniorocznych wskaźników wzrostu wynagrodzeń w państwowej sferze budżetowej obliguje Radę Ministrów do uwzględnienia w projekcie ustawy budżetowej wynagrodzeń zapewniających osiągnięcie uzgodnionej wysokości wskaźników. Z kolei w razie braku wspomnianego uzgodnienia bądź niedotrzymania przez Radę Dialogu Społecznego terminów ustawowych Rada Ministrów przyjmuje do projektu ustawy wskaźniki wzrostu wynagrodzeń, nie niższe jednak od tych, które zostały określone w propozycji złożonej Radzie. W sposób zbliżony do powyższego określono też uzgadnianie minimalnego wynagrodzenia. Rada Dialogu Społecznego po otrzymaniu propozycji Rady Ministrów uzgadnia wysokość wynagrodzenia minimalnego oraz ustala minimalną stawkę godzinową, które podlegają ogłoszeniu w Dzienniku Urzędowym „Monitor Polski” w drodze obwieszczenia Prezesa Rady Ministrów w terminie do dnia 15 września każdego roku. Jeżeli jednak uzgodnienie i ustalenie nie nastąpią, Rada Ministrów ustali je w drodze rozporządzenia, z zastrzeżeniem, że kwoty wymienionych wyżej wynagrodzeń nie mogą być niższe od wysokości określonych w propozycji skierowanej do Rady Dialogu Społecznego. Podobne zasady obowiązują przy uzgadnianiu kwot zwiększenia wskaźnika waloryzacji emerytur i rent na rok następny ${ }^{34}$ oraz wysokości kwot zasiłków rodzinnych i świadczeń rodzinnych ${ }^{35}$.

30 Zob. uwagi S. Patyry, Konsultacje społeczne..., s. 504. Por. w tym zakresie stanowisko TK z dnia 18 stycznia 2005 r., K 15/03.

31 Zob. S. Patyra, Konsultacje społeczne..., s. 502.

32 Na podstawie ustawy z dnia 23 grudnia 1999 r. o kształtowaniu wynagrodzeń w państwowej sferze budżetowej oraz zmianie niektórych ustaw, tekst jedn. Dz.U. z 2018 r., poz. 373.

33 Ustawa z dnia 10 października 2002 r. o minimalnym wynagrodzeniu za pracę, tekst jedn. Dz.U. z 2017 r., poz. 847.

34 Ustawa z dnia 17 grudnia 1998 r. o emeryturach i rentach z Funduszu Ubezpieczeń Społecznych, tekst jedn. Dz.U. z 2015 r., poz. 748.

35 Ustawa z dnia 28 listopada 2003 r. o świadczeniach rodzinnych, Dz.U. z 2003 r., nr 228, poz. 2255 ze zm. 
Podsumowując, można powiedzieć, że kompetencje Rady Dialogu Społecznego ze względu na jej trójpodmiotową strukturę, łączącą współpracę strony społecznej ze stroną rządową, ukazują jej szczególną pozycję w procesie tworzenia prawa. Rzeczywisty udział partnerów społecznych w procesie prawotwórczym uzależniony jest jednak od sposobu i jakości współpracy stron kierujących się zasadą solidarności społecznej i budowania społecznego porozumienia.

\section{Struktura oraz pozycja stron Rady Dialogu Społecznego}

Trójstronny dialog społeczny na poziomie centralnym to inaczej forum współpracy pomiędzy partnerami społecznymi, reprezentującymi środowiska społeczno-gospodarcze oraz państwem, reprezentowanym przez stronę rządową. Jego ogólnie ujmowany cel, wpisujący się w aksjologię społecznej gospodarki rynkowej, określany jest mianem dbałości o dobro wspólne obywateli, a także, jak się podkreśla, stanowi „synonim społeczeństwa obywatelskiego, aktywnie angażującego się w życie publiczne $[\ldots]^{\prime 36}$. Ze względu na powyższy schemat i strukturę podmioty będące stronami dialogu odpowiedzialne są również za kierunki polityki społeczno-gospodarczej.

W uzasadnieniu do projektu ustawy z 2015 r. wskazano, że otwarcie na dialog społeczny i współdziałanie z partnerami społecznymi ma szczególne znaczenie dla umocnienia demokratycznego charakteru państwa, zaufania obywateli do jego instytucji oraz efektywnej kontroli administracji publicznej ${ }^{37}$. Poskutkowało to, jak już zaznaczono wcześniej, ustaleniem szerokiego zakresu spraw, w ramach których prowadzi się dialog społeczny, jak również przyznaniem szczególnych kompetencji stronie społecznej Rady. Przy wstępnej ocenie przepisy ustawy wydają się adekwatne do tego, w jaki sposób powinna wyglądać współpraca rządu z partnerami społecznymi w nowych uwarunkowaniach społeczno-gospodarczych. Weryfikacja powyższej tezy wymaga jednak przeprowadzenia dodatkowych rozważeń, o czym niżej.

W skład Rady Dialogu Społecznego wchodzą przedstawiciele pracowników, pracodawców i rządu. Zgodnie z art. 1 ust. 1 u.r.d.s. (in fine) określane są one mianem jej stron. Takiego statusu nie posiadają inne podmioty, biorące udział w jej pracach na zaproszenie Przewodniczącego Rady ${ }^{38}$ lub strony społecznej ${ }^{39}$. Dotyczy

36 Por. uwagi S. Patyry, Konsultacje społeczne..., s. 497-498.

37 Zob. uzasadnienie do projektu Rady Ministrów z dnia 17 czerwca 2015 r., VII.3519, dostępne na: https://sip.lex.pl/\#/act-project/102089708/1 (dostęp: 20.09.2018).

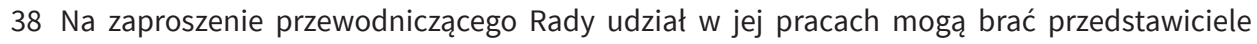
organizacji lub instytucji, zgodnie z ich zakresem działania.

39 Organizacje reprezentatywne pracowników i pracodawców mogą zapraszać przedstawicieli innych związków i organizacji związkowych, organizacji społecznych bądź zawodowych. 
to także ex lege uczestniczących w posiedzeniach Rady przedstawicieli Prezydenta Rzeczypospolitej Polskiej, Prezesa Narodowego Banku Polskiego, Prezesa Głównego Urzędu Statystycznego i Głównego Inspektora Pracy. Mają oni przy tym wyłącznie głos doradczy.

Stronę społeczną w Radzie tworzą członkowie reprezentatywnych organizacji związkowych. Kryteria reprezentatywności oraz tryb orzekania o niej zostały uregulowane odpowiednio w art. 23, 24 i 25 u.r.d.s. ${ }^{40}$ Przy tym na uwadze należy mieć zmiany powyższych przepisów od 1 stycznia 2019 r., o których była mowa wcześniej, podyktowane rozszerzeniem kręgu podmiotowego wolności zrzeszania się o osoby wykonujące pracę zarobkową. Takie podejście ustawodawcy, bazujące na przyznaniu szczególnych uprawnień organizacjom reprezentatywnym, nie dziwi - występowało ono zresztą w poprzedniej ustawie i stanowi dość typowe rozwiązanie w zakresie reprezentowania strony społecznej. Stronę rządową reprezentują tymczasem członkowie Rady Ministrów, a także przedstawiciel ministra właściwego do spraw pracy odpowiedzialnego za dialog społeczny oraz przedstawiciel ministra właściwego do spraw finansów publicznych odpowiedzialnego za budżet - w randze sekretarza lub podsekretarza stanu. Każda z organizacji reprezentatywnych i strona rządowa działają przez swoich przedstawicieli. Ustawodawca wprowadza zasadę równej liczby przedstawicieli ze strony pracowniczej i pracodawczej, z zastrzeżeniem, że od 31 sierpnia 2018 r. nie może być więcej niż 25 przedstawicieli w ramach danej strony, a każda z organizacji reprezentatywnych powinna mieć równą liczbę przedstawicieli w Radzie. W szczególnych przypadkach - ze względu na brak możliwości ustalenia równej liczby reprezentantów - różnica w liczbie jest dopuszczalna, ale nie może wynieść więcej niż jeden. Z kolei liczbę przedstawicieli ze strony rządowej ustala Prezes Rady Ministrów. Wniosek w przedmiocie powołania przedstawicieli składają odpowiednio właściwe organizacje pracowników, organizacje pracodawców i Prezes Rady Ministrów, a ich powołanie i odwołanie należy do kompetencji Prezydenta Rzeczypospolitej Polskiej.

Mając na względzie powyżej opisane zasady reprezentacji stron, ustawodawca określa warunki przyjmowania uchwał. Uchwały trójstronne podejmowane są pod warunkiem uczestniczenia w posiedzeniu Rady przedstawicieli więcej niż połowy organizacji reprezentatywnych ze strony pracowników i pracodawców ${ }^{41}$ oraz co najmniej jednego przedstawiciela Rady Ministrów. Przyjęcie wspomnianej uchwały wymaga zgody każdej ze stron Rady, przy czym stanowiska strony pracowników i strony pracodawców są przyjmowane zwykłą większością, podczas gdy stanowisko strony rządowej powinno zostać przyjęte jednomyślnie przez obecnych na posiedzeniu członków Rady Ministrów oraz przedstawicieli ministra właściwego

40 J. Piątkowski, Komentarz do ustawy o organizacjach pracodawców, [w:] Zbiorowe prawo pracy. Komentarz, Warszawa 2016, art. 16, pkt 4-6.

41 Wymagane jest uczestniczenie w głosowaniu co najmniej dwóch trzecich członków Rady reprezentujących daną stronę. 
do spraw pracy i ministra właściwego do spraw finansów publicznych. Uchwały dwustronne strony społecznej w przedmiocie wniosku, opinii albo zajmowanego stanowiska podejmowane są na odpowiednio podobnych zasadach.

Pracami Rady Dialogu Społecznego kieruje Prezydium, w skład którego wchodzą przewodniczący i wiceprzewodniczący wskazani przez każdą organizację reprezentatywną oraz przez stronę rządową. W związku z powyższym w Prezydium reprezentowana jest zarówno strona społeczna, jak i strona rządowa. Przewodniczącym Rady jest naprzemiennie przedstawiciel strony pracowników i strony pracodawców, wskazywany przez daną stronę albo członek strony rządowej, wskazywany przez Prezesa Rady Ministrów. Rozwiązanie takie stanowi zasadniczą zmianę w porównaniu do przepisów poprzednio obowiązującej ustawy. W ówczesnym stanie prawnym przewodniczącym Komisji mógł być wyłącznie przedstawiciel rządu. W uzasadnieniu do projektu ustawy podkreślono, że w kontekście nadania nowych uprawnień stronie pracowników i stronie pracodawców takie uregulowania mają na celu uniezależnienie Rady od strony rządowej. W ramach Rady działają też zespoły problemowe, składające się z przedstawicieli jej stron: ds. budżetu, wynagrodzeń i świadczeń socjalnych, ds. prawa pracy, ds. polityki gospodarczej i rynku pracy, ds. ubezpieczeń społecznych, ds. rozwoju dialogu społecznego, ds. funduszy europejskich, ds. usług publicznych, ds. międzynarodowych oraz zespół doraźny ds. zamówień publicznych. W skład każdego z nich wchodzi po dwóch przedstawicieli każdej z organizacji reprezentatywnych pracowników i pracodawców oraz strony rządowej. Dodatkowo wybierany jest też przewodniczący zespołu, którym może być naprzemiennie przedstawiciel strony pracowników i strony pracodawców Rady.

Przy określaniu pozycji stron Rady Dialogu Społecznego na podkreślenie zasługuje wydzielenie dwóch podstawowych płaszczyzn, w ramach których działają jej strony. Na powyższe rozwarstwienie kompetencji wskazuje już tytuł rozdziału II ustawy, stanowiący o uprawnieniach Rady Dialogu Społecznego i jej stron. Powyższy sposób ujęcia kompetencji określany jest mianem dychotomii w zakresie funkcjonowania Rady albo jej dwupoziomowych kompetencji ${ }^{42}$. Połączenia dialogu trójstronnego i autonomicznego w jednym akcie prawnym, ze względu na współzależności, jakie występują w dialogu, nie należy jednak oceniać krytycznie. Co ważne, większość z tzw. kompetencji obligatoryjnych i zdefiniowanych zostało przekazanych na szczebel autonomiczny partnerów społecznych. Poza prawem opiniowania aktów prawnych Rady Ministrów (art. 5 u.r.d.s.) strona społeczna przedstawia wspólną opinię w przedmiocie Wieloletniego Planu Finansowego Państwa, a także wspólną propozycję wzrostu wynagrodzeń w gospodarce narodowej, minimalnego wynagrodzenia za prace oraz emerytur i rent z FUS, jak również wyraża wspólne stanowisko $\mathrm{w}$ sprawie założeń projektu ustawy budżetowej oraz w sprawie projektu ustawy budżetowej (art. 16-18 u.r.d.s.). W odnie- 
sieniu do ostatnich z wymienionych kompetencji występuje tzw. trójwariantowa formuła konsultacji ${ }^{43}$. W razie braku wspólnie uzgodnionego stanowiska każda ze stron może przedstawić swoje stanowisko, z kolei nieprzedstawienie stanowiska przez strony umożliwia przedstawienie opinii przez każdą z organizacji, której przedstawiciele wchodzą w skład strony. Co ważne, ustawodawca w tych przypadkach za pomocą terminów ustawowych określa konsekwencje braku uzgodnienia wspólnego stanowiska, opinii i propozycji, uznając, że niedotrzymanie terminów jest równoznaczne $\mathrm{z}$ rezygnacją $\mathrm{z}$ wykonania uprawnienia przez stronę społeczną (art. 19 ust. 1 in fine).

Na gruncie przedmiotowej ustawy doszło do rozszerzenia kompetencji partnerów społecznych ${ }^{44} \mathrm{w}$ obszarze stanowienia prawa. Realizowane są one w formie uchwał dwustronnych. Strona społeczna Rady ma prawo występowania ze wspólnymi wnioskami o wydanie lub zmianę ustawy albo innego aktu prawnego (art. 13 u.r.d.s.). Wniosek złożony w powyższym trybie obliguje właściwego ministra do przedstawienia pisemnego stanowiska Rady Ministrów w sprawie. Ponadto, strona pracowników i pracodawców ma prawo do przygotowywania wspólnie uzgodnionych projektów założeń projektów ustaw i projektów aktów prawnych oraz do przekazania ich właściwemu ministrowi w celu przedłożenia Radzie Ministrów (art. 7 u.r.d.s.). Nieprzyjęcie przez Radę Ministrów projektu do dalszych prac zobowiązuje właściwego ministra do przedstawienia stronie społecznej pisemnego uzasadnienia; z kolei w przypadku wniesienia projektu ustawy do Sejmu $\mathrm{z}$ istotnymi zmianami, informacja zawierająca uzasadnienie zmian powinna być zamieszczana w uzasadnieniu projektu. Również w odniesieniu do kompetencji, o których mowa w art. 5 u.r.d.s., jeżeli Rada Ministrów nie uwzględni opinii strony społecznej albo dokona istotnych zmian w projekcie w stosunku do opiniowanego projektu, ma obowiązek przedstawienia swojego stanowiska w treści uzasadnienia projektu przedłożonego Sejmowi, jak również przekazywania go Radzie. Powyższe kompetencje w zakresie współtworzenia prawa zostały wzmocnione uprawnieniem strony społecznej do składania wniosków o przeprowadzenie wysłuchania publicznego do podmiotu odpowiedzialnego za opracowanie projektu aktu normatywnego (art. 8 u.r.d.s.) oraz kierowania zapytania do właściwego ministra (art. 9 u.r.d.s.). W tym drugim przypadku właściwy minister udziela odpowiedzi w terminie 30 dni od dnia otrzymania wspólnego zapytania. Wskazać należy też na kompetencję strony społecznej do zawierania ponadzakładowych układów zbiorowych pracy (art. 15 u.r.d.s.), obejmujących ogół pracodawców zrzeszonych w organizacjach reprezentatywnych lub grupę tych pracodawców oraz pracowników przez nich zatrudnionych.

43 O tym: S. Patyra, Konsultacje społeczne..., s. 502.

44 Zob. o uprawnieniach reprezentatywnych organizacji pracodawców jako strony Rady: J. Piątkowski, Komentarz do ustawy..., art. 16, pkt 12-17. 
Na koniec warto też wspomnieć o uprawnieniach strony społecznej w obszarze stosowania prawa, które polegają na prawie do składania wniosków do Sądu Najwyższego o rozstrzygnięcie zagadnienia prawnego (art. 14 u.r.d.s.) oraz wniosków do ministra właściwego do spraw finansów publicznych o wydanie interpretacji ogólnej w przypadku niejednolitego stosowania przepisów prawa podatkowego (art. $14 b$ u.r.d.s.).

Inaczej sprawa wygląda $\mathrm{w}$ odniesieniu do uchwał trójstronnych, podejmowanych przez wszystkie strony Rady Dialogu Społecznego. Uwagę w tym zakresie zwraca dość lakoniczne i ogólne uregulowanie dialogu trójstronnego w przedmiotowej ustawie. Artykuły 3 i 4 u.r.d.s. wskazują na prawo do zawierania porozumień oraz zajmowanie wspólnego stanowiska, a także podejmowanie uchwał w sprawach o dużym znaczeniu społecznym lub gospodarczym oraz w sprawach wniesionych pod obrady przez Radę Ministrów, jej członków i inne organy państwowe.

W podsumowaniu uwag na temat pozycji stron Rady na podkreślenie zasługuje zatem nie tylko umiejscowienie większości kompetencji Rady w ramach dialogu autonomicznego, ale również zdecydowane rozszerzenie jego formuły. Trafnie zauważa się, że zasadnicza różnica pomiędzy poprzednio funkcjonującą Trójstronną Komisją a Radą Dialogu Społecznego „polega na upodmiotowieniu działań, inicjatyw i decyzji podejmowanych w układzie dwustronnym (strony pracowników i strony pracodawców), które skierowane są do strony rządowej”45. Uwagę zwraca zatem, podkreślana w literaturze, zdecydowana autonomizacja dialogu społecznego. Jak zauważa J. Wratny, ustanowione forum dialogu przybliża go do idei demokracji partycypacyjnej oraz konsensualnej, a nawet do idei demokracji perswazyjnej ${ }^{46}$.

\section{Uwagi końcowe}

1. Ustawa zasadnicza odwołuje się do dialogu społecznego jako podstawowego kierunku współpracy władzy publicznej z partnerami społecznymi, mając na celu uzyskanie społecznego poparcia w odniesieniu do prowadzonych polityk. Instytucję, w ramach której powyższa współpraca jest prowadzona stanowi Rada Dialogu Społecznego. Zastąpiła ona działającą od 1994 r. Trójstronną Komisję do Spraw Społeczno-Gospodarczych, w wyniku czego doszło też do jakościowej zmiany w zakresie celów, zadań i instrumentów działania Rady. Ustawodawca określa Radę mianem forum trójstronnej współpracy strony pracowników, strony pracodawców oraz strony rządowej, w ramach której dialog prowadzony jest w celu zapewnienia warunków

45 J. Męcina, Komentarz do ustawy o Radzie Dialogu Społecznego..., art. 2, teza 2.

46 Tak J. Wratny, Rada Dialogu Spotecznego..., s. 5. 
rozwoju społeczno-gospodarczego, zwiększenia konkurencyjności polskiej gospodarki i spójności społecznej. Spowodowało to pojawienie się głosów, że przepisy obecnej ustawy sytuują się bliżej prawa konstytucyjnego, chociaż tradycyjnie dialog społeczny uważany jest za instytucję zbiorowego prawa pracy ${ }^{47}$.

2. Przyjęta formuła dialogu ma na celu uspołecznienie procesów prawotwórstwa oraz wyrównywanie niedostatków demokracji parlamentarnej. Podkreśla się w związku z tym, że obecnie wpisuje się ona w ramy koncepcji demokracji uczestniczącej, co dalej zacieśnia związki ustawy z obszarem prawa konstytucyjnego ${ }^{48}$. Jako główny mankament obecnej regulacji wymienia się pominięcie wśród stron prowadzących dialog czwartej siły w postaci grup społeczeństwa obywatelskiego. Chodzi tu o organizacje wywierające zasadniczy wpływ na życie kraju, z którymi państwo nie może się nie liczyć. De lege lata ich uczestnictwo jest warunkowe oraz odbywa się ad hoc, bez nadania uprawnień przysługujących stronom. Przy tym podkreśla się, że demokratyczny i zrównoważony rozwój społeczny wymaga - poza stworzeniem nowych płaszczyzn dialogu - także przybrania szerszej formuły dialogu obywatelskiego ${ }^{49}$. Ze względu na specyfikę funkcjonowania w Polsce reprezentatywnych przedstawicielstw pracowników i pracodawców również dalsze odpolitycznianie strony społecznej dialogu jest jak najbardziej wskazane ${ }^{50}$.

3. Na gruncie przedmiotowej ustawy w wyniku dopuszczenia partnerów społecznych do uczestnictwa w wytyczaniu kierunków polityki społeczno-gospodarczej w szerokim obszarze spraw nastąpiło istotne wzmocnienie pozycji strony społecznej w procesie tworzenia prawa. Zyskała ona ponadto nowe kompetencje, określane mianem quasi-inicjatywy legislacyjnej. Wyrażają się one w prawie do przygotowywania projektów ustaw i występowania $z$ wnioskiem o wydanie lub zmianę aktu prawnego. Przyjętego sposobu zakreślenia ogólnych ram dla trójstronnego dialogu społecznego oraz zdecydowaną autonomizację dialogu strony społecznej nie należy poddawać krytyce.

Przy tym nasuwa się nawet dalej idące pytanie o możliwość uczynienia udziału strony społecznej bardziej stanowczym, w tym poprzez zastąpienie aktualnych kompetencji opiniodawczo-konsultacyjnych formułą zgody ${ }^{51}$. Chodzi zatem

47 Ibidem, s. 4. Por. też uwagi w przedmiocie umiejscowienia dialogu jako instytucji zbiorowego prawa pracy: K. Walczak, Dialog społeczny... oraz E. Wronikowska, Dialog społeczny jako podstawowa zasada zbiorowego prawa pracy w Polsce, [w:] A. M. Świątkowski (red.), Studia z zakresu prawa pracy i polityki społecznej, Kraków 2007.

48 J. Wratny, Rada Dialogu Społecznego..., s. 5.

49 Ibidem.

50 Oceny wspomnianego udziału oraz uwagi de lege ferenda w odniesieniu do ustawy o Komisji Trójstronnej ds. Społeczno-Gospodarczych dokonał M. Włodarczyk w opracowaniu: Udział partnerów społecznych w tworzeniu ustawowego prawa pracy, [w:] Z. Hajn, D. Skupień (red.), Przyszłość prawa pracy..., s. 481-491, zob. zwłaszcza uwagi na s. 490.

51 Na przykład poprzez akceptację projektu oraz jego zmian. Por. o tym: M. Włodarczyk, Udział partnerów społecznych..., s. 489-490. 
o zwiększenie merytorycznego znaczenia konsultacji społecznych i zdecydowane wyjście poza etap formalnego postępowania w procesie prawotwórczym. De lege lata pojawia się bowiem niebezpieczeństwo lekceważenia bądź omijania procedur konsultacyjnych, m.in. poprzez przygotowywanie projektów poselskich, $\mathrm{w}$ ramach których powyższe procedury nie obowiązują. Powyższa propozycja, poza zaletami, ma jednak wady, a zatem wymaga dalszych przemyśleń i uszczegółowień. Jako pierwszy krok w kierunku jej wdrażania wskazano potrzebę poszerzenia składu strony społecznej, a tym samym składu Rady, wychodząc poza ramy reprezentatywnych organizacji związkowych pracowników i pracodawców ${ }^{52}$.

4. Niezależność strony społecznej Rady Dialogu Społecznego znajduje też wyraz w przepisach określających skład, organizację i podejmowanie uchwał Rady. Dodatkowo, uniezależnienie od rządu oraz wzmocnienie pozycji partnerów społecznych przejawia się w rotacyjności i kadencyjności przewodniczenia pracom Rady. Do zadań jej przewodniczącego poza funkcją reprezentacyjną i sprawozdawczą należy też kierowanie wniosków i zapytań do właściwych organów, a także wykonywanie innych czynności zleconych przez Radę. Jawność posiedzeń Rady oraz informowanie społeczeństwa o decyzjach i udziale przedstawicieli strony społecznej w procesie stanowienia prawa może dodatkowo przyczynić do promocji dialogu społecznego jako skutecznego forum współpracy rządu z partnerami społecznymi.

5. Ogólnie rzecz ujmując, sposób, w jaki uregulowano uspołecznienie mechanizmów podejmowania decyzji publicznych oraz pozyskania społecznego przyzwolenia dla prowadzenia polityk społeczno-gospodarczych, zasługuje na pozytywną cenę. W szczególności służy temu rozszerzenie obszarów prowadzenia dialogu społecznego oraz zdecydowane poszerzenie kompetencji strony społecznej w procesie stanowienia, a także ujednolicania prawa. Bez wątpienia nową jakość dialogowi na forum Rady nadało zastąpienie celów stricte pracowniczych celami ogólnospołecznymi, w tym zwłaszcza ekonomicznymi. Jednak, jak trafnie się zauważa, istnienie stosownych przepisów nie jest jedynym warunkiem gwarantującym efektywność dialogu społecznego. Chodzi tu bowiem zwłaszcza o „praktykę współdziałania stron i panujący klimat" ${ }^{33}$, a więc przede wszystkim prowadzenie

52 Por. uwagi J. Wratnego, Rada Dialogu Społecznego..., s. 6. Do niedawna istotną przeszkodę stanowita w tym zakresie specyfika funkcjonowania reprezentatywnych organizacji związkowych ze strony pracowników, wynikająca z prawa koalicji, adresowanego zasadniczo do pracowników. Od 2019 r., mając na względzie zmianę ustawy, argument ten przestaje mieć znaczenie. Na podstawie ustawy z dnia 5 lipca 2018 r. o zmianie ustawy o związkach zawodowych oraz niektórych innych ustaw (Dz.U. z 2018 r., poz. 1608) prawo tworzenia i wstępowania do związków zawodowych przysługuje osobom wykonującym pracę zarobkową w rozumieniu ustawy, a więc prawo koalicji będzie miało zdecydowanie szerszą formułę.

53 Por. uwagi K. Walczaka oraz powoływane przez autora opracowania w: Dialog społeczny..., s. 978. 
dialogu w dobrej wierze ${ }^{54}$ oraz z poszanowaniem interesów każdej ze stron w imię nadrzędnego celu, jakim jest dobro społeczne ${ }^{55}$. Doświadczenia $\mathrm{z}$ lat dziewięćdziesiątych, skutkujących przyjęciem „Paktu o przedsiębiorstwie państwowym w trakcie przekształcania”, potwierdzają, że istotna jest nade wszystko wola wspólnych uzgodnień i towarzysząca temu kultura negocjacyjna ${ }^{56}$.

\section{Santrauka}

\section{Socialinio Dialogo Taryba kaip Vyriausybès ir socialinių partnerių (visuomenès) bendradarbiavimo būdas}

1. Socialinis dialogas nustatytas Lenkijos Respublikos Konstitucijoje kaip vienas iš pagrindinių viešosios valdžios institucijų ir socialinių partnerių bendradarbiavimo būdų, siekiant gauti viešąją paramą, reikalingą vykdomai politikai. Institucija, kurioje šis bendradarbiavimas vykdomas, yra Socialinio Dialogo Taryba. Ši institucija pakeitè nuo 1994 m. veikusią Trišalę socialinių ir ekonominių reikalų komisiją. Tokiu būdu buvo pasiekti kokybiniai pokyčiai nustatant socialinio dialogo tikslus, užduotis ir priemones šiam dialogui vystytis.

2. Naujo socialinio dialogo tikslas - suvisuomeninti ịstatymų leidybos procesus ir pašalinti parlamentinès demokratijos trūkumus. Pagrindinis dabartinio teisinio reglamentavimo trūkumas yra ketvirto socialinio dialogo partnerio - pilietinių visuomenių grupių - ignoravimas. Tai yra organizacijos, turinčios esminę reikšmę šalies gyvenimui ir kurių valstybè negali nepaisyti. De lege lata jų dalyvavimas yra sąlyginis ir vyksta ad hoc nesuteikiant teisių kitoms šalims.

3. Teigiamai vertintinas būdas, kuriuo suvisuomenintas svarbių visuomenei sprendimų prièmimas bei gaunant visuomenės pritarimą vykdant socialinès - ekonominès politikos sprendimus. Tai, visų pirma, lemia socialinio dialogo išplètimą bei socialinio partnerio kompetencijos išplètimą kuriant bei standartizuojant teisę. Neabejotina, kad naujajam dialogui didelę reikšmę turèjo tai, kad Tarybai svarbūs ne tik darbuotojų tikslai, bet ir bendri visuomeniniai tikslai, tame tarpe ir ekonominiai. Tačiau, kaip teisingai pažymima, tinkamų teisès nuostatų egzistavimas neužtikrina socialinio dialogo veiksmingumo. Tai ypač aktualu „šalių bendradarbiavimui ir vyraujančiam klimatui“, taigi visų pirma svarbu sąžiningai vesti socialinị dialogą gerbiant kiekvienos šalies interesus ir siekiant svarbiausio tikslo - socialinès gerovès.

54 Por. uwagi dotyczące rokowań prowadzonych w dobrej wierze: L. Florek, Komentarz do art. 2413 k.p., [w:] Kodeks pracy. Komentarz, Warszawa 2017.

55 Por. też uwagi M. Pliszkiewicza, wskazującego na cechy efektywnego dialogu w: Warunki trójstronnego dialogu..., s. 475-578.

56 Por. ibidem. 


\section{Literatura}

Florek L., Komentarz do art. 2413 k.p., [w:] Kodeks pracy. Komentarz, Warszawa 2017.

Florek L., Prawnomiedzynarodowe uwarunkowania zakładowego dialogu społecznego, [w:] J. Stelina (red.), Zakładowy dialog społeczny, Warszawa 2014.

Męcina J., Komentarz do ustawy o Radzie Dialogu Społecznego i innych instytucjach dialogu społecznego, [w:] Zbiorowe prawo pracy. Komentarz, Warszawa 2016.

Patyra S., Konsultacje społeczne w procesie przygotowywania rządowych projektów ustaw - zarys problemu, „Studia Iuridica Lublinensia” 2014, nr 22.

Piątkowski J., Komentarz do ustawy o organizacjach pracodawców, [w:] Zbiorowe prawo pracy. Komentarz, Warszawa 2016.

Pliszkiewicz M., Warunki trójstronnego dialogu społecznego, [w:] Z. Hajn, D. Skupień (red.), Przyszłość prawa pracy. Liber Amicorum. W pięćdziesięciolecie pracy naukowej Profesora Michała Seweryńskiego, Warszawa 2016.

Sanetra W., Prawnokonstytucyjne uwarunkowania zakładowego dialogu partnerów społecznych, [w:] J. Stelina (red.), Zakładowy dialog społeczny, Warszawa 2014.

Walczak K., Dialog społeczny, [w:] System zbiorowego prawa pracy, t. V: Zbiorowe prawo pracy, red. K. W. Baran, Warszawa 2014.

Włodarczyk M., Udział partnerów społecznych $w$ tworzeniu ustawowego prawa pracy, [w:] Z. Hajn, D. Skupień (red.), Przyszłość prawa pracy. Liber Amicorum. W pięćdziesięciolecie pracy naukowej Profesora Michała Seweryńskiego, Warszawa 2016.

Wratny J., Rada Dialogu Społecznego. Czy jeszcze instytucja zbiorowego prawa pracy?, „Praca i Zabezpieczenie Społeczne" 2016, nr 10.

Wronikowska E., Dialog społeczny jako podstawowa zasada zbiorowego prawa pracy w Polsce, [w:] A. M. Świątkowski (red.), Studia z zakresu prawa pracy i polityki społecznej, Kraków 2007.

Uzasadnienie do projektu Rady Ministrów z dnia 17 czerwca 2015 r., VII.3519, dostępne na: https://sip.lex.pl/\#/act-project/102089708/1 (dostęp: 20.09.2018).

\section{Akty prawne}

Konstytucja Rzeczypospolitej Polskiej z dnia 2 kwietnia z 1997 r., Dz.U. z 1997 r., nr 78, poz. 483.

Ustawa z dnia 23 maja 1991 r. o związkach zawodowych, Dz.U. z 2015 r., poz. 1881; Dz.U. z 2018 r., poz. 1608.

Ustawa z dnia 17 grudnia 1998 r. o emeryturach i rentach z Funduszu Ubezpieczeń Społecznych, tekst jedn. Dz.U. z 2015 r., poz. 748.

Ustawa dnia 23 grudnia 1999 r. o kształtowaniu wynagrodzeń w państwowej sferze budżetowej oraz zmianie niektórych ustaw, tekst jedn. Dz.U. z 2018 r., poz. 373. 
Ustawa o Komisji Trójstronnej ds. Społeczno-Gospodarczych i wojewódzkich komisjach dialogu społecznego z dnia 6 lipca 2001 r., Dz.U. z 2001 r., nr 100, poz. 1080 ze zm.

Ustawa z dnia 10 października 2002 r. o minimalnym wynagrodzeniu za pracę, tekst jedn. Dz.U. z 2017 r., poz. 847.

Ustawa z dnia 28 listopada 2003 r. o świadczeniach rodzinnych, Dz.U. z 2003 r., nr 228, poz. $2255 \mathrm{ze} \mathrm{zm}$.

Ustawa z dnia 15 czerwca 2018 r. o zmianie ustawy o Radzie Dialogu Społecznego i innych instytucjach dialogu społecznego, Dz.U. z 2018 r., poz. 1464.

Ustawa z dnia 5 lipca 2018 r. o zmianie ustawy o związkach zawodowych oraz niektórych innych ustaw, Dz.U. z 2018 r., poz. 1608.

Uchwała Sejmu RP z dnia 30 lipca 1992 r. - Regulamin Sejmu Rzeczypospolitej, tekst dostępny na: http://www.sejm.gov.pl/prawo/regulamin/kon7.htm (dostęp: 20.09.2018).

Obwieszczenie Prezesa Rady Ministrów z dnia 11 października 2016 r. w sprawie ogłoszenia jednolitego tekstu uchwały Rady Ministrów - Regulamin pracy Rady Ministrów, M.P. z 2016 r., poz. 1006. 